\title{
THE EFFECT OF IRRIGATING BY MAGNETIZED WATER, PROLINE AND YEAST EXTRACT SPRAYING ON QUALITY AND PRODUCTIVITY OF TOMATO CROP UNDER SALT STRESS CONDITIONS.
}

\author{
A.S. EL_Sayed ${ }^{1}$ and A.E. M. Eata ${ }^{2}$
}

\section{ABSTRACT}

This research aims to rationalize the applications of water and mineral fertilizers for tomato crop, in order to obtain clean organic food, and to maintain the quality and quantity of production. Three biological treatments were applied: first using magnetization technology to improve the drainage water ability to reuse it. Second using proline as an amino acid and third using yeast extraction as an alternative fertilizer. The applied treatments included three levels of magnetized water (1000, 2000 and 3000 gauss); two levels of proline $(50 \& 100 \mathrm{ppm})$ and two levels of yeast extract at concentrations of $(5 \& 10 \%)$ compared with control treatment. Whereas, five of groups of measurements were carried out to; illustrate the effects of the applied treatment. The measurements were deduced on each of: soil properties, crop growth indicators, flowering time, crop yield and crop quality. The gained results of the present study indicated that applying the magnetized water $(3000 \mathrm{G})$ with proline $(100$ ppm) at $10 \%$ yeast extract reduces the electrical conductivity (EC) by reduction ratios of (45.09\& $50.19 \%)$, while the soil acidity reduced by $(28.93 \& 25.08 \%)$ than control through the tested seasons. Also, the mean increment ratios of the plant heights were increased by $(25.19$ \& $25.41 \%)$ than control. However, the flowering period was increased up to 88 days. The quality indicators ratios (T.S.S and vit. C) were increased by $\{(9.39 \& 9.0)$ and $(34.2 \% \& 33.50) \%\}$ orderly, while tomato acidity and blossom end rote ratios were decreased by $\{(7.90 \& 8.0)$ and $(0.390 \&$ $0.405) \%\}$ only than control. As well, the increment ratios in crop yield (y) and the net earn were $\{(30.10 \& 27.87)$ and (33.19\& $30.24 \%)$ orderly than control for (2015 \& 2016) seasons.

Key words: Magnetization, electrical conductivity, proline, EC, yeast.

${ }^{1}$ Researcher, Agric. Eng. Res. Inst., Agric. Res. Center, Egypt.

${ }^{2}$ Researcher, Hort. Res. Inst., Agric. Res. Center, Egypt. 


\section{INTRODUCTION}

Tomato is an important vegetable crop not only for its economic importance but also for its nutritional value. It is essentially

1 present in all countries either as open field or protected crops. As other countries, it is one of the most important vegetable crops in Egypt and used for food and industrial purpose (Giovannucci, 1999). Egypt has a few environmental issues that need to be dealt with. Agricultural land is being lost to urbanization and wind-blown sands. The soil salination below Aswan High Dam is increasing which is negative for many crops especially since there is little rainfall to lower the soil $\mathrm{pH}$. The review could be split into the main branches as the following:

\section{Factors affecting tomato quality:}

However (Magkos et al. 2003) stated that good quality of tomato fruits and their acceptance by consumers describes a high correlation coefficient between the results of sensory assessment and the results of chemical analysis. Also (Beckles, 2011\& Siddiqui, 2015) stated that tomato solids are very valuable at the factory processing. Higher amount of tomato solids need less amount of fruits to produce the same amount of tomato products. Total dry matter content in different tomato cultivars varies from $4 \%$ to $7.5 \%$ of fruit fresh mass. Soluble solids account for $75 \%$ of the total solids and are comprised primarily of the reducing sugars, which represent $55-65 \%$ of the total soluble solids content. As well (Voogt, 1998) showed that potassium $(\mathrm{K}), \mathrm{Mg}$, and $\mathrm{Ca}$ are vital nutrients in tomato production, and deficiencies of these elements usually occur due to undersupply or antagonistic effects on each other thus decreasing growth, yield, and quality of tomato. Generally a lack of a specific element is not only restricted to bad management of the fertilizer program but also to antagonism between elements that is sometimes difficult to prevent. This is the case for $\mathrm{K}, \mathrm{Mg}$, and $\mathrm{Ca}$ that strongly interfere with each other during the uptake process. However Blossom-end rot is a common physiological fruit disorder in tomato. In susceptible cultivars, it may cause severe economic losses in some seasons and under certain environmental conditions (Taylor and Locascio, 2004). 


\section{The need of magnetization in tomato crop:}

Topcu et al., (2006) stated that water resources is represent one of the most important problems which affect agriculture worldwide due to the lack of it. Deficit irrigation is an optimization strategy that allows to some extent of water stress during a certain cropping stage or the whole season without a significant reduction in yield.

However (Costa et al., 2007) said that tomato (Solanum lycopersicon L.) is one of the most important vegetable crops and is one of the most demanding in terms of water use (Peet, 2005). The application of DI strategies to this crop may significantly led to save irrigation water. As well (Alsadon et al., 2009) showed that tomato is classified as moderately tolerant crop to salinity at all plant developmental stages. Whereas (Lim and Ogata, 2005) stated that for maximum yield, the electrical conductivity (EC) of soil extracted from the root zone and in the irrigation water should not exceed $2.5 \mathrm{dSm}^{-1}$. Higher salinity levels (12 $\mathrm{dSm}^{-1}$ ) caused a significant reduction in total fruits yield $(49.7 \%)$ in comparison with the control $\left(1.2 \mathrm{dSm}^{-1}\right)$, while a moderate level (2.4 $\mathrm{dSm}^{-1}$ ) had no significant effect in this concern. According to (Olympios et al., 2003), increasing EC of irrigation water from 1.5 to 3.2 $\mathrm{dSm}^{-1}$ did not affect the vegetative growth, but the yield was $45 \%$ less. Also, (Chibowski et al. 2005) showed that magnetized water is obtained by passing of water through the permanent magnets or through the electro magnets installed in/on a feed pipeline. When a fluid passes through the magnetized field, its structure and some physical characteristic such as density, salt solution capacity, and deposition ratio of solid particles will be changed. The changes caused by the magnetic influence depend on many factors, such as strength of the magnetic field, direction of applied magnetized field, duration of magnetic exposure, flow rate of the solution, additives present in the system, and the $\mathrm{pH}$. Too (Hilal and Hillal 2000) showed that the magnetized water have three main effects; first: increasing the leaching of excess soluble salts, second: lowering soil alkalinity and third dissolving slightly soluble salts such carbonates, phosphates and sulfates. They indicated that, the effectiveness degree of magnetized water on soil salinity and ionic balances in soil solution 
depend greatly on the traveling distance of magnetized water along the drip irrigation lines. In that manner (Amiri and Dadkhah 2006) indicated that, changes in surface tension due to magnetic treatment can be a key point in tracing impurities in water. Meaningful changes in surface tension of a liquid sample after a day can be a good indicator for the presence of physical and chemical changes in the sample. As well, (Tai et al., 2008) is observed that, subjecting water to magnetic field, lead to modification of its properties, as it becomes more energetic and more able to flow which can be considered as a birth of new science called Magneto biology. They pointed out that, magnetized water prevents harmful metals (such as, lead and nickel) from uptake by roots and reaching fruits and roots. However, it also increases the percentage of nutrient elements like phosphorus, potassium and zinc. However (Maheshwari and Grewal, 2009) said that, the use of magnetically treated irrigation water reduced soil $\mathrm{pH}$ but increased available $\mathrm{P}$ in celery and snow pea. Overall, the results indicate some beneficial effect of magnetically treated irrigation water, particularly for saline water and recycled water, on the yield and water productivity. Whereas, (Behrouz et al., 2010) evaluated the magnetized water which obtained by passing water through a strong permanent magnet installed in or on a feed pipeline. They showed that, irrigation with magnetic water as compared with the nonmagnetic water increased soil moisture up to $7.5 \%$, and this increase was significant at the $1 \%$ level. Also, the effect of irrigation water salinity on soil moisture was significant. They recommended use of magnetized water for irrigation is to save irrigation water.

\section{Effect of proline on tomato crop:}

Proline is one of the compatible osmolytes induced by stress in plants. Several functions are proposed for the accumulation of proline in tissues exposed to stress $\mathrm{C}$ and $\mathrm{N}$ reserves for growth after stress relief (Hayashi et al., 2000), anti-oxidation (Hoque et al., 2007), the stabilisation of proteins and membranes and the protection of macromolecules from denaturation (Hamilton \& Heckathorn, 2001), osmo-protection, and as a reducing power and available energy source. The effect of proline is dependent on its concentration. However proline 
is synthesized not only from glutamate, but also from arginine/ornithine. The enzymes involved in the proline biosynthetic pathway of both prokaryotic and eukaryotic systems, including higher plants as well as the network of pathways. However (Zhu , 2001) found that intermediates of proline biosynthesis and catabolism such as glutamine and P5C could increase the expression of several osmotically regulated genes in rice such as salt and the dehydrin dhn 4. Also, gene induction by P5C did not depend on the de novo protein synthesis and respiration. Plants treated with $\mathrm{P} 5 \mathrm{C}$ and its analogue 3, 4-dehydroproline consumed less $\mathrm{O}_{2}$, displayed more NADH levels, but reduced NADPH levels and accumulated several osmolytes associated with dehydrated plants of rice. As well (Matysik et al., 2002) indicated that proline plays an important role during development of plants, especially in flowers and also in pollen serving as a readily accessible source of energy. It is known that oxidation of one molecule of proline yields $30 \mathrm{ATP}_{\mathrm{s}}$. Besides (Sivakumar et al., 2000) showed that proline may interact with enzymes to preserve protein structure and activities. Protection of structural and functional integrity of M4 lactate dehydrogenase by proline has been reported. Indeed, proline has been shown in vitro to reduce enzyme denaturations caused due to heat, $\mathrm{NaCl}$ stress, etc. Presence of high concentrations of proline and/or betaine gives better protection against the biologically unfavorable consequences of dehydration-induced thermodynamic perturbations.

\section{Effect of yeast on tomato crop:}

In addition, bio-fertilization is very safe for human, animal and environment to get lower pollution and reduce soil salinity via decrease mineral usage fertilization as well as saving fertilization cost. The possibility of using the active bread yeast for improving growth and productivity of fruit crops was reported by Stino et al., (2009). However, the various positive effects of applying active bread yeast as a new biofertilizer were attributed to its own component from different nutrients, higher percentage of proteins, massive amount of vitamin $B$ and the natural plant growth hormone namely cytokinins. In addition, application of active bread yeast was very effective in releasing $\mathrm{CO}_{2}$, which reflected on improving net photosynthesis (Hashem et al., 2008). Application of 
yeasts as bio control agents acts as a new trend against different pathogens. Potential use of yeasts as bio control agents of soil borne fungal plant pathogens and as plant growth promoters were recent investigated by Silva and Bettiol (2005). Active dry yeast is considered as bio-stimulant, natural source of cytokinins that stimulates cell division and enlargement as well as the synthesis of protein, nucleic acid and chlorophyll formation (Wanas and trails, 2006). Moreover, it contains cryoprotective agent, i.e. sugars, proteins, amino acids and also several vitamins (Mahmoued, 2001). It may enhance water holding capacity, increase antioxidants, and enhance metabolism (Abbas, 2013). Bread yeast (Saccharomyces cerevisiae) is usually added to soil or as foliar application to crops due to its content of many nutrient elements as well as its role in producing important substances like growth regulators such as gibberellins, auxins and its ability to produce a group of enzymes (Dinkha and Al-Khazragji, 1990).

The main objective of the present research is to reduce mineral fertilizing by using natural alternative sources such as the amino acid (proline) and the yeast extraction on the strategic crop like tomato's to get massive production with high quality. Also reducing the plant water consumption with raising the drainage water ability through application the magnetization characteristics.

\section{MATERIALS AND METHODS}

Field experiments were carried out during two consecutive agricultural seasons (2015 and 2016) on the fayroz tomato species. Where a strategic crop such as; tomato was selected, it is a moderate salt stress crop and also its need high water consumption rates as it is an economic crop which enters into most foods because it contains many vitamins and minerals. A soil affected by salinity in Al_Serw area was selected and the use of agricultural drainage water was used for irrigation to study the effect of the biological factors under study on the yield production and the quality of tomato crop. Soil samples were taken at a depth of $(0-30 \mathrm{~cm})$ before and after planting to estimate some of the physical and chemical properties, as listed in table (1). Also the chemical analysis for drainage 
water samples, which were taken from the used drainage tunnel before and after applying treatments, was listed in table (1).

Table.1: The chemical analysis of the tested soils and the drainage irrigation water before and after applying the tested treatments.

\begin{tabular}{|c|c|c|c|c|c|c|c|c|}
\hline Parameters & \multicolumn{4}{|c|}{ Soil analysis } & \multicolumn{4}{|c|}{ Drainage water analysis } \\
\hline \multirow{2}{*}{ Seasons } & \multicolumn{2}{|c|}{2015} & \multicolumn{2}{|c|}{2016} & \multicolumn{2}{|c|}{2015} & \multicolumn{2}{|c|}{2016} \\
\hline & Before & After & Before & After & Before & After & Before & After \\
\hline pH & 8.40 & 4.35 & 7.90 & 4.95 & 7.50 & 4.20 & 6.40 & 3.95 \\
\hline $\mathrm{EC}, \mathrm{dSm}^{-1}$ & & 2.81 & & & 4.40 & & & 2.11 \\
\hline $\mathrm{Ca}^{++}, \mathrm{me} \mathrm{L}^{-1}$ & 9.50 & 12.33 & 11.50 & 13.55 & 12.55 & & & 21.22 \\
\hline $\mathrm{Mg}^{++}, \mathrm{me} \mathrm{L}^{-1}$ & 5.21 & 8.25 & 5.80 & 7.80 & 10.96 & 12.55 & 12.55 & 15.21 \\
\hline $\mathrm{Na}^{++}, \mathrm{me} \mathrm{L}^{-1}$ & 8.22 & 4.21 & 6.80 & 3.24 & 17.33 & 8.11 & 12.55 & 9.21 \\
\hline $\mathbf{K}^{+}, \quad$ me $\mathbf{L}^{-1}$ & 1.75 & 2.75 & 1.90 & 2.66 & 0.71 & 2.14 & 0.45 & 1.56 \\
\hline $\mathrm{Co}_{3}^{--}, \mathrm{me} \mathrm{L}^{-1}$ & 3.00 & 3.50 & 2.50 & 3.66 & 2.88 & 3.65 & 2.51 & 3.65 \\
\hline $\mathrm{Hco}_{3}{ }^{--}$, me L L & 3.20 & 4.25 & 2.88 & 3.18 & 4.30 & 5.65 & 4.0 & 5.41 \\
\hline $\mathrm{Cl}^{-}, \quad$ me $\mathrm{L}^{-1}$ & 7.55 & 5.55 & 6.34 & 5.33 & 14.45 & 12.25 & 16.39 & 12.55 \\
\hline $\mathrm{So}_{4}^{--}, \mathrm{me} \mathrm{L}^{-1}$ & 5.58 & 6.55 & 10.99 & 11.0 & 5.93 & 6.99 & 8.44 & 9.48 \\
\hline
\end{tabular}

The tested variables used to increase the quality and the yield productions of the tomato crop were divided into three main parameters:

\section{Magnetic water device:}

The use of magnetic technology is one of the modern techniques that gave excellent results to increase the validity of the drainage water used to irrigate the salted affected soils. Where, most of these devices consist of a fixed natural magnetic field that is formed around plastic pipes with small diameters. The effect of the magnetic field depends on the strength of the permanent magnet, which weakens after a period of operation. In addition, the cost of these units is large. Therefore, an electromagnetic device with variable magnetic flow densities that could be tuned with the irrigation density was developed (El-Sayed at al., 2015). This new unit was installed on the traditional portable irrigation pumps, as shown in Fig. (1). It was electronically controlled by an electronic device, as shown in Fig. (3), which regulated the pump discharge rate to synchronize the magnetic field density strength with the outlet water quantity. This unit 
contains buttons to choose the magnetic density and LCD screen which appears the number of coils used and the operation time through using its keyboard. This unit is $12 \mathrm{~V}$ DC which regulates the inlet electrical intensity up to $40 \mathrm{~A}$ by its own rheostat system. The flywheel of irrigation pump was modified by installed a connected pulley with $(16.5 \mathrm{~cm}$ Dia.) and V belt shape $(13 \times 1100 \mathrm{~mm})$ connected to DC generator (model Denso (140 A \& $13.5 \mathrm{~V}$ ) and an electric battery (40 amp) to supply unit with the necessary electrical DC power, as shown in Fig. (1). The electromagnetic device formed from an electromagnetic field generator which consists from four copper coils with $10 \mathrm{~mm}$ thickness that distributed intently around 4" diameter of the outer circumference of discharge pipe. Every pair of coils was settled versus to each other's to generate powerful electromagnetic field density ranged from (1000 to $3000 \mathrm{G}$ ), as shown in Figs. (2\&3). Furthermore, the magnetic coils were attached through heavy metal cylinder with dimensions of $(17 \times 10.16 \times 1 \mathrm{~cm})$ (Length- Dia.- Thick.).

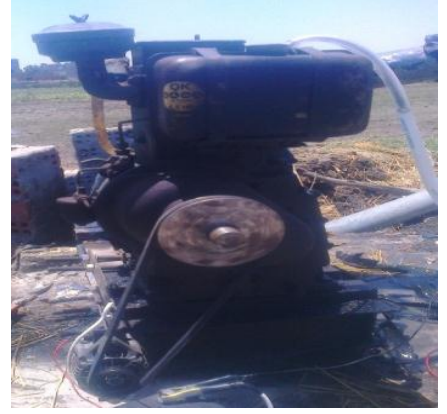

Fig.1: The modified portable irrigation pump model GAWA (6.5 hp).

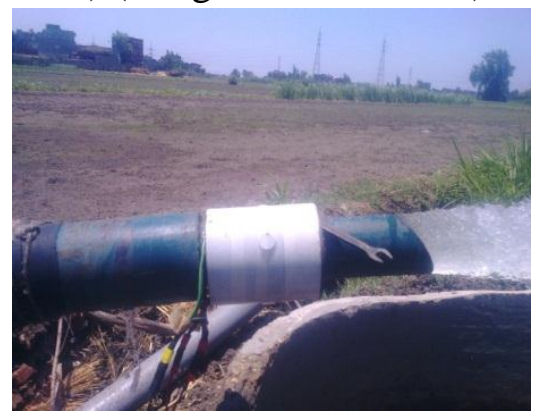

Fig.2: The electromagnetic outlet irrigation pipe.

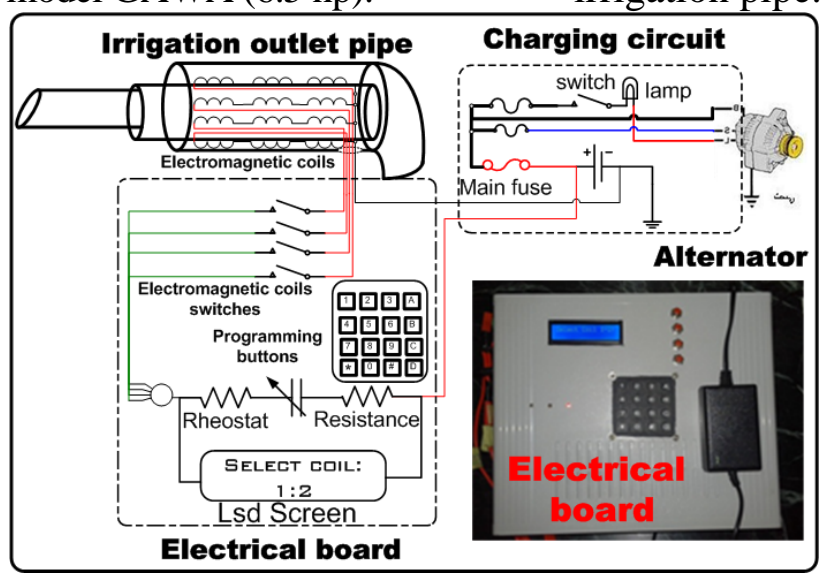

Fig.3: The electromagnetic system. (El-Sayed et al., 2015) 
2. Amino acid proline treatment: Proline $(\mathrm{P})$ is an $\alpha$-amino acid that is used in the biosynthesis of proteins and producing ATP which enlarging the plants ability of bearing stress. It was prepared by adding ( $5 \& 10 \mathrm{~g} \mathrm{P} / 100$ lit water) for one feddan to get concentrations of (50 $\& 100 \mathrm{ppm})$.

3. Yeast extract treatment: Which prepared by adding $1 \mathrm{~kg}$ of bread yeast (Saccharomyces cerevisiae) plus $2 \mathrm{Kg}$ molasses were brewed for 24 hours then take (5 or 10 lit) from the mixed solution that diluted into 100 liter water/feddan to get ( $5 \& 10 \%$ concentrations) and then sprinkled on the plants in the early morning three times every (20, 40 and 60 day) after the transplantation by the back gasoline motors. Yeast extract was used on the tomato crop at the fruit growth stage and increased in size (when the size of the tomato is as olive or slightly larger). The purpose was to increase the size of the fruits and their growth speed. When yeast was lifted in the water it decomposed to a large number of vitamins and amino acids, but the most important of them all is cytokinins, which is the basis of root stimulation, and increased the rate of vegetative growth in the first ages of plant life. Cytokinins affect the cellular division of the fruit, especially the step (DNA replication) (Al-Yahyai, 2010).

\section{The experimental procedure and variables:}

The field experiments were carried out at El-Serw Agricultural Research Station Damietta Governorate during two crop summer seasons of (2015\&2016) of using the agricultural drainage water under the following study variables:-

1- Three levels of magnetized water $\left(\mathbf{G}_{\mathbf{w}}\right)$ : with three different electromagnetic densities of $(1000,2000$ and $3000 \mathrm{G})$ which controlled through using the electronic attached device for magnetization.

2- Two levels of amino acid proline (P): (50 and $100 \mathrm{ppm}$ ) which added using back gasoline motors.

3- Two levels of yeast extract (Y): (5 and $10 \%)$ concentrations which added also using back gasoline motors.

(Notice: all the tested variables were compared to the untreated control plots)

\section{Experimental design:}

The experimental layouts were a split-plot system in a randomized complete blocks design with three replications. Magnetized water 
irrigation treatments were randomly allocated to the main plots where the proline treatments were the sub-plots, and the yeast extracts were the subsub plots respectively. The sub-plot area was $20 \mathrm{~m}^{2}$ including 36 plots. The planting was on $120 \mathrm{~cm}$ ridges with $40 \mathrm{~cm}$ distances between plants at the summer seasons of (2015 \& 2016). Fruits for quality evaluation were harvested at the full color maturity stage at two different dates: at the beginning of May and at the end of June. At each harvest time, 40 fruits were collected from each combination. A random samples of fruits (approximately $2 \mathrm{~kg}$ from the first and second trusses) were taken from each experimental unit at the peak of harvesting (the fourth picking) for laboratory analyses. An analysis of variance was conducted separately within each year. Differences among the means were evaluated for significance using a revised least significant difference (L.S.D.) test at 0.05 levels. The traits were statistically analyzed using Statistical Analysis System (Costat) version (6) (Oida, 1997).

\section{Measurements}

1) Electrical conductivity (EC), $\mathbf{d S m}^{-\mathbf{1}}$ : was determined in the laboratory using 1:5 soil water extract and electrical conductivity bridge.

2) $\mathbf{p H}$ : values were measured in the laboratory using soil water suspensions $1: 2.5$ and the $\mathrm{pH}$ meter.

3) Germination ratio, (G) \%: For treated plots. It was calculated by the following equation:-

$$
G=\frac{\text { n.of germinated seeds,plant }}{\text { all n.of cultivated seeds,plant }} \times 100 .
$$

4) Plant height (H), cm: Using meter at the end of plant life before harvesting from the stalk over the ground to the plant top.

5) Plant leaves area (A), $\mathbf{c m}^{2}$ : By collecting leaves and distributed it using an image scanner and image analysis software.

6) Chlorophyll level percentage, (ch) \%: It was estimated by the following equation:-

$$
\text { ch }=\frac{\text { control plots plants leaves chloropyll percentage }, \mathbf{m g} / \mathbf{c m}^{2}}{\text { tested plots plants leaves chloropyll percentage, } \mathbf{m g} / \mathbf{c m}^{2}} \times 100 \ldots
$$




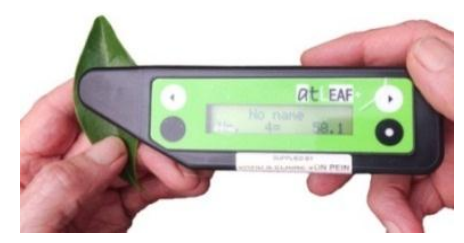

Fig.4: Digital Chlorophyll Meter model atLEAF.

7) Plant flowering time, (F) day: By observing it in records until harvesting.

8) Total crop yield, (Y) ton/fed: By calculating the average fruit weight by dividing the total weight of all harvested fruits from each sub-plot across the whole season by their number to the unit area.

9) Tomato quality (T.S.S, Vit. C, Acidity and blossom end rote ratios \%):

The homogenized fruits juice was subjected to the following determinations; total soluble solids (T.S.S, ${ }^{\circ}$ Brix) using a portable refractometer, vitamin $\mathrm{C}$ content using the pigment of 2,6dichlorophenol-indophenol while, acidity $(\mathrm{pH})$ was measured with a glass electrode $\mathrm{pH}$ meter. The mineral content was determined by atomic absorption spectrophotometry previous to nitric digestion; except for phosphorous which was measured by a colorimetric method, using the Vanadate-Molybdate reagent.

10) Economic evaluation: All the necessary expenses were calculated from the process of cultivation, processing of land to harvest in comparison between the transactions used for the same area and the control to determine the net profit according to the local prices at the harvest time in the two tested seasons.

\section{RESULTS AND DISCUSSION}

\section{1- Electrical conductivity(EC)}

The effects of the three applied treatments $\left(G_{w}, P\right.$ and $\left.Y\right)$ on the electrical conductivity (EC, dsm- ${ }^{1}$ ) at two different seasons are illustrated in Figs. (5\&6). In reality, increasing the electromagnetic field density for the magnetized water $\left(\mathrm{G}_{\mathrm{w}}\right)$ minimizes the electrical conductivity (EC, dsm- $\left.{ }^{1}\right)$ with raising the treatments of the $(\mathrm{P} \& \mathrm{Y})$ in contrary relationships. The maximum mean values of $\left(\mathrm{EC}, \mathrm{dsm}^{-}\right)$were $\left(5.81 \& 5.12 \mathrm{dsm}^{-1}\right)$ respectively for the two tested seasons without using magnetized water for control plots, 
while the lowest mean values of the (EC, dsm- $\left.{ }^{1}\right)$ were $\left(3.19 \& 2.55 \mathrm{dsm}^{-1}\right)$ for (2015 \& 2016) seasons respectively for $3000 \mathrm{G}$ of $\left(\mathrm{G}_{\mathrm{w}}\right)$ at $(\mathrm{P})$ of $100 \mathrm{ppm}$, as shown in Fig. (5). The reduction ratios in EC were (45.09 \& 50.19\%) respectively than control. On the contrary the mean maximum values of (EC, $\mathrm{dsm}^{1}{ }^{1}$ ) were $\left(5.54 \& 4.95 \mathrm{dsm}^{-}\right)$, as shown in Fig. (6) without using magnetized water for control plots, while the lowest mean values of the (EC, $\left.\mathrm{dsm}^{-}{ }^{1}\right)$ were $\left(3.63 \& 2.75 \mathrm{dsm}^{-1}\right)$ for $3000 \mathrm{G}$ of $\left(\mathrm{G}_{\mathrm{w}}\right)$ at $(\mathrm{Y})$ of $10 \%$. Thus the reduction ratios in (EC) were (34.48 \& 44.44\%) respectively than control for (2015 \& 2016) seasons respectively. These results may be attributed to by increasing the electromagnetic field densities for the used magnetized water slashed the composited salinity crystals into smaller unaffected ones, which decreased the osmotic stress to let the plant roots absorb the nutrients from the soil. However, using proline reduced, also the plant strain with the mixing of using yeast extract. Besides, using magnetization led to increasing the period between irrigations which decrease relatively the consumed water quantity in irrigation. Statically, there are high significant effects for the total interaction between different treatments with $(\mathrm{P}<0.05)$ for the $(\mathrm{EC})$ values. Thus, ANOVA analysis indicated highly significant differences between the treatments.

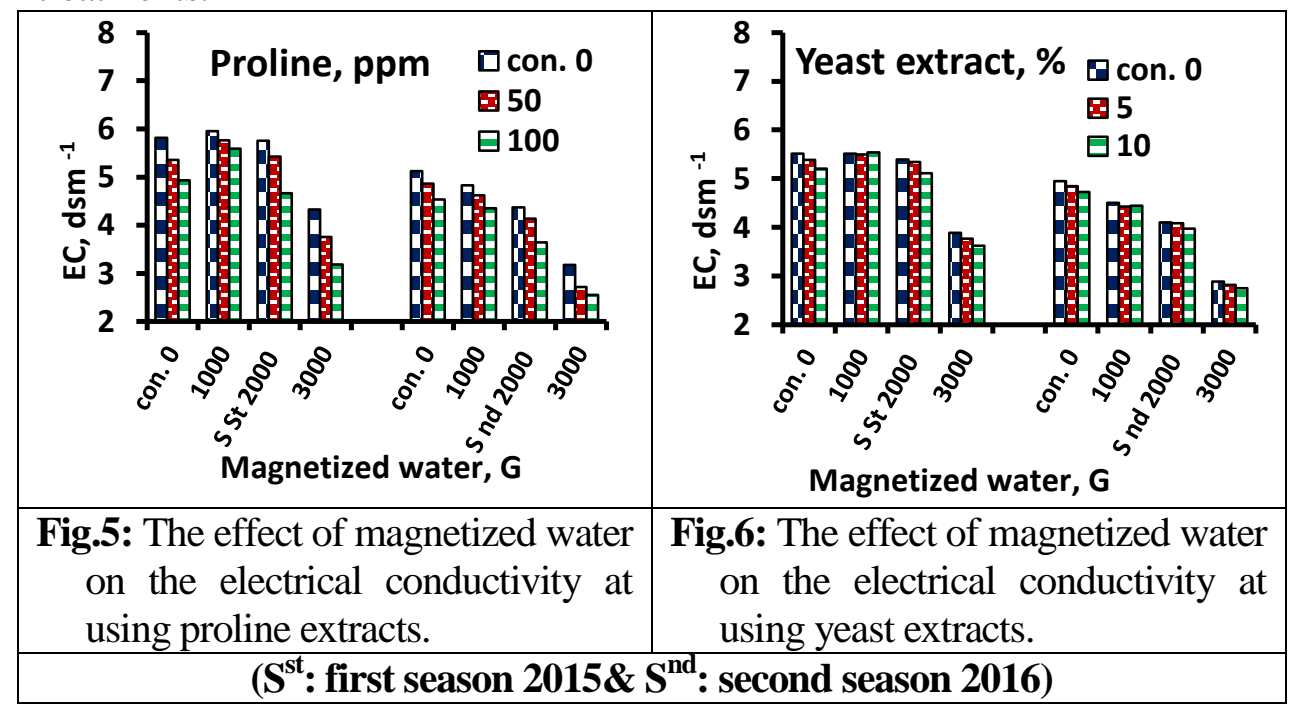

A simple power regression analysis applied to relate the change in (EC) with the change in the tested factors for all treatments. The obtained regression equations for the two different seasons were in the form of: 
$\left(\right.$ EC S $\left.{ }^{\text {St }}\right) \mathrm{dsm}^{-1}=5.888-5.063 \mathrm{e}^{-4} \mathrm{~W}(\mathrm{G})-0.0024 \mathrm{P}(\mathrm{ppm})-0.0051 \mathrm{Y}(\%)$ $\left(\mathbf{R}^{2}=0.9591 \& \mathbf{C .} \mathbf{V}=4.238\right)$

$\left(\right.$ EC S $\left.^{\text {nd }}\right) \mathrm{dsm}^{-1}=5.132-6.487 \mathrm{e}^{-4} \mathrm{~W}(\mathrm{G})-0.00204 \mathrm{P}(\mathrm{ppm})-0.0028 \mathrm{Y}(\%)$

$\left(\mathbf{R}^{2}=0.9654\right.$ \& $\left.\mathbf{C} . \mathbf{V}=4.682\right)$

\section{2- Soil (pH)}

As shown in Figs. ( $7 \& 8)$ the effects of the three applied treatments $\left(G_{w}, P\right.$ and $\mathrm{Y})$ on the soil $\mathrm{pH}$ two different seasons are illustrated. In that manner, raising the electromagnetic field density for the magnetized water $\left(G_{w}\right)$ decreases the soil $\mathrm{pH}$ levels with increasing the treatments of the $(\mathrm{P} \& \mathrm{Y})$ in opposite relationships. The highest mean values of $(\mathrm{pH})$ were $(7.50 \& 7.0)$ without using magnetized water for control plots, as the lowest mean values of the $(\mathrm{pH})$ were $(5.33 \& 4.77)$ for $3000 \mathrm{G}$ of $\left(\mathrm{G}_{\mathrm{w}}\right)$ at $(\mathrm{P})$ of $100 \mathrm{ppm}$, as shown in Fig. (7). The reduction ratios in $\mathrm{pH}$ were $(28.93 \& 31.86 \%)$ than control for (2015 \& 2016) seasons respectively. As well, the maximum mean values of $(\mathrm{pH})$ were (7.44 \& 6.77), as shown in Fig. (8) without using magnetized water for control plots, while the lowest mean values of the $(\mathrm{pH})$ were $(5.57$ $\& 4.95)$ for $3000 \mathrm{G}$ of $\left(\mathrm{G}_{\mathrm{w}}\right)$ at $(\mathrm{Y})$ of $10 \%$. Also the reduction ratios in $\mathrm{pH}$ were $(25.13 \& 26.88 \%)$ than control for (2015 \& 2016) seasons respectively. These results may be referred to by increasing the electromagnetic field densities the soil $\mathrm{pH}$ decreases due to minimize the $\mathrm{NaCl}$ crystals and change the $\mathrm{pH}$ number for the soil with using the proline and yeast extract.

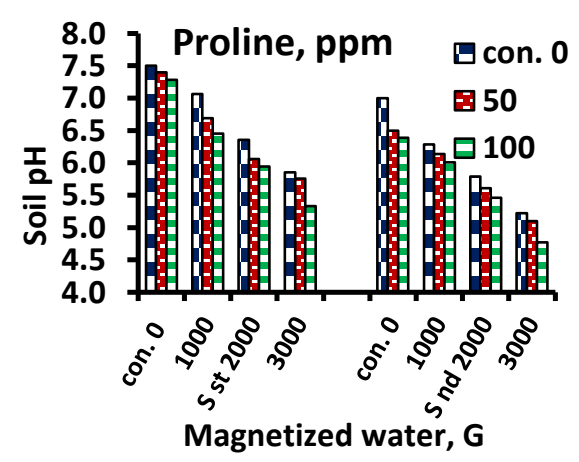

Fig.7: The effect of magnetized water on the soil $\mathrm{pH}$ at using proline extracts.

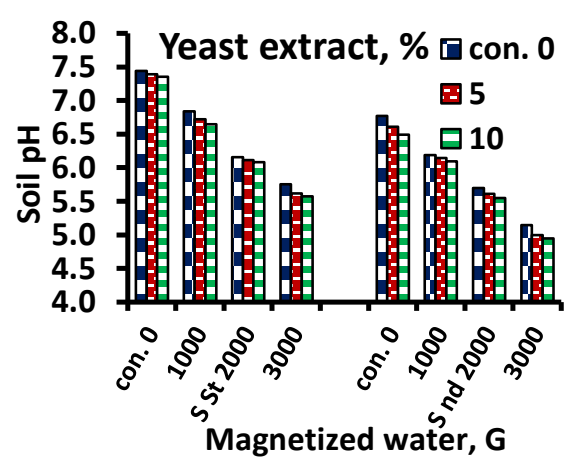

Fig.8: The effect of magnetized water on the soil $\mathrm{pH}$ at using yeast extracts. 
Thus, ANOVA analysis indicated highly significant differences between the treatments. Statically, there are high significant effects for the total interaction between different treatments with $(\mathrm{P}<0.05)$ for the $(\mathrm{pH})$ values. A simple power regression analysis applied to relate the change in $(\mathrm{pH})$ with the change in the tested factors for all treatments. The obtained regression equations for the two different seasons were in the form of:

$\left(\right.$ pH S $\left.{ }^{\text {St }}\right) \%=7.639-5.8514815 \mathrm{e}^{-4} \mathrm{~W}(\mathrm{G})-0.0044 \mathrm{P}(\mathrm{ppm})-0.0132 \mathrm{Y}(\%)$ $\left(\mathbf{R}^{2}=0.9952 \& \mathbf{C} . \mathbf{V}=0.9030\right)$

$$
\begin{aligned}
& \left(\mathbf{p H ~ S} \mathbf{S}^{\mathbf{n d}}\right) \%=6.951-5.305 \mathrm{e}^{-4} \mathrm{~W}(\mathrm{G})-0.0042 \mathrm{P}(\mathrm{ppm})-0.0181 \mathrm{Y}(\%) \\
& \left(\mathbf{R}^{2}=0.9989 \& \mathbf{C . V}=0.431\right)
\end{aligned}
$$

\section{3- Germination percentage (G)}

Furthermore, the effects of the three applied treatments $\left(G_{w}, P\right.$ and $\left.Y\right)$ on the germination percentage $(\mathrm{G}, \%)$ at two different seasons are emerge in Figs. (9\&10). Moreover, increasing the electromagnetic field density for the magnetized water $\left(G_{w}\right)$ increases the plant height values $(G, \%)$ with increasing the treatments of the $(\mathrm{P} \& \mathrm{Y})$ in direct relationships. The lowest mean values of $(\mathrm{G})$ were $(70.19 \& 72.23 \%)$ without using magnetized water for control plots, while the maximum mean values of the $(\mathrm{G})$ were $(95.65 \&$ $96.41 \%$ ) for $3000 \mathrm{G}$ of $\left(\mathrm{G}_{\mathrm{w}}\right)$ at $(\mathrm{P})$ of $100 \mathrm{ppm}$, as shown in Fig. (9). The increment ratios in $\mathrm{G}$ were $(26.62 \& 25.08 \%)$ than control for (2015 \& 2016) seasons respectively. Besides, the minimum mean values of $(\mathrm{G})$ were $(71.86$ \& $74.01 \%$ ), as shown in Fig. (10) without using magnetized water for control plots, during the maximum mean values of the $(\mathrm{G})$ were $(93.81 \&$ $95.16 \%)$ for $3000 \mathrm{G}$ of $\left(\mathrm{G}_{\mathrm{w}}\right)$ at $(\mathrm{Y})$ of $10 \%$. Too, the increment ratios in $(\mathrm{G})$ were $(23.40 \& 22.23 \%)$ than control for (2015 \& 2016) seasons respectively. These results by reason of raising the ability of drainage water which treated by magnetization with using the amino acid proline that maximize the germination ratio with mix of using yeast extract which contains some nutrients for the germinated seeds. There are high significant effects statically for the total interaction between different treatments with $(\mathrm{P}<0.05)$ for the $(\mathrm{H})$ values. As well, ANOVA analysis indicated highly significant differences between the treatments. A simple power regression analysis applied to relate the change in $(\mathrm{G})$ with the change in the tested factors for all treatments. The obtained regression equations for the two different seasons were in the 
form of: $\left(\mathbf{G ~ S ~}^{\mathrm{St}}\right) \%=70.949+0.0066 \mathrm{~W}(\mathrm{G})+0.0442 \mathrm{P}(\mathrm{ppm})+0.128 \mathrm{Y}(\%)$ $\left(\mathbf{R}^{2}=0.9986 \& \mathbf{C . V}=0.419\right)$

$\left(\right.$ G S $\left.^{\text {nd }}\right) \%=73.64625+0.0063 \mathrm{~W}(\mathrm{G})+0.0383 \mathrm{P}(\mathrm{ppm})+0.141 \mathrm{Y}(\%)$ $\left(\mathbf{R}^{2}=0.9988 \& \mathbf{C} . \mathbf{V}=0.368\right)$

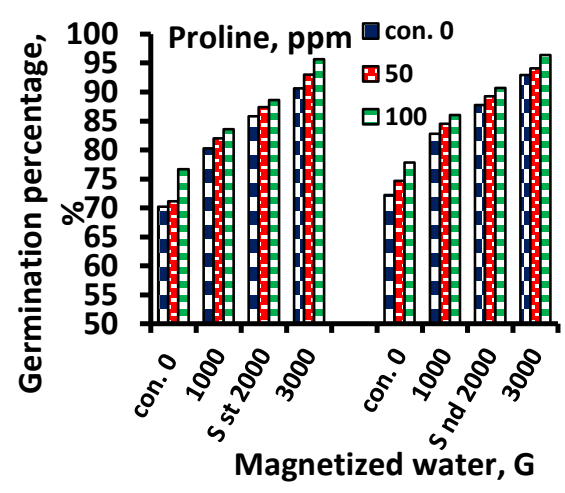

Fig.9: The effect of magnetized water on the germination percentage at using proline extracts.

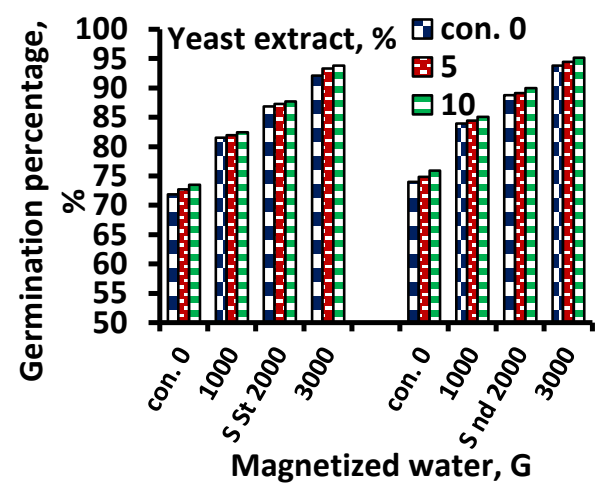

Fig.10: The effect of magnetized water on the soil germination percentage at using yeast extracts.

\section{4- Plant height (H)}

Indeed the effects of the three applied treatments $\left(G_{w}, P\right.$ and $\left.Y\right)$ on the plant height $(\mathrm{H}, \mathrm{cm})$ at the two different seasons are illustrated in Figs. (11 \& 12). Despite, raising the electromagnetic field density for the magnetized water $(\mathrm{G}$ w) increases the plant height values $(\mathrm{H}, \mathrm{cm})$ with increasing the treatments of the $(\mathrm{P} \& \mathrm{Y})$ in direct relationships. The minimum mean values of $(\mathrm{H})$ were $(40.22 \& 41.16 \mathrm{~cm})$ without using magnetized water for control plots, while the maximum mean values of the $(\mathrm{H})$ were $(53.79 \& 55.18 \mathrm{~cm})$ for $3000 \mathrm{G}$ of $\left(\mathrm{G}_{\mathrm{w}}\right)$ at $(\mathrm{P})$ of $100 \mathrm{ppm}$, as shown in Fig. (11). The increment ratios in $\mathrm{H}$ were ( $25.19 \& 25.41 \%)$ than control for (2015 \& 2016) seasons respectively.

Like this, the lowest mean values of $(\mathrm{H})$ were $(41.15 \& 41.89 \mathrm{~cm})$, as shown in Fig. (12) without using magnetized water for control plots, while the maximum mean values of the $(\mathrm{H})$ were $(52.41 \& 53.49 \mathrm{~cm})$ for $3000 \mathrm{G}$ of $\left(\mathrm{G}_{\mathrm{w}}\right)$ at $(\mathrm{Y})$ of $10 \%$. Too, the increment ratios in $\mathrm{H}$ were $(21.48 \& 21.69)$ than control for (2015 \& 2016) seasons respectively. These results by reason of magnetization let nutrients in available case which increases the vegetative growth in the aid of proline which produces the ATP and also the yeast cytokinins which help to build plant tissues. Nevertheless, ANOVA analysis 
indicated highly significant differences between the treatments. Also statically there are high significant effects for the total interaction between different treatments with $(\mathrm{P}<0.05)$ for the $(\mathrm{H})$ values. A simple power regression analysis applied to relate the change in $(\mathrm{H})$ with the change in the tested factors for all treatments. The obtained regression equations for the two different seasons were in the form of:

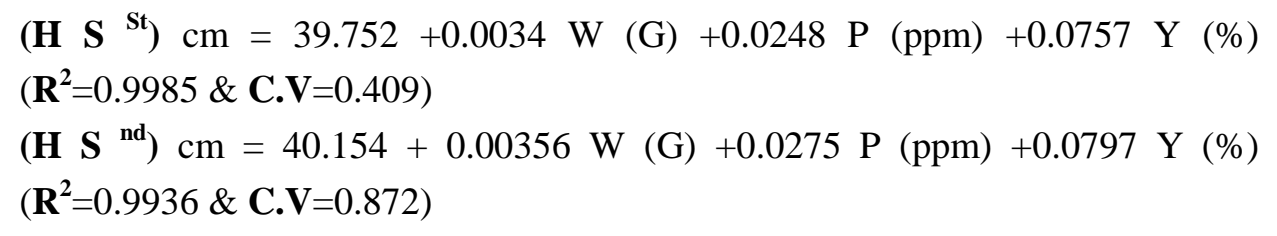

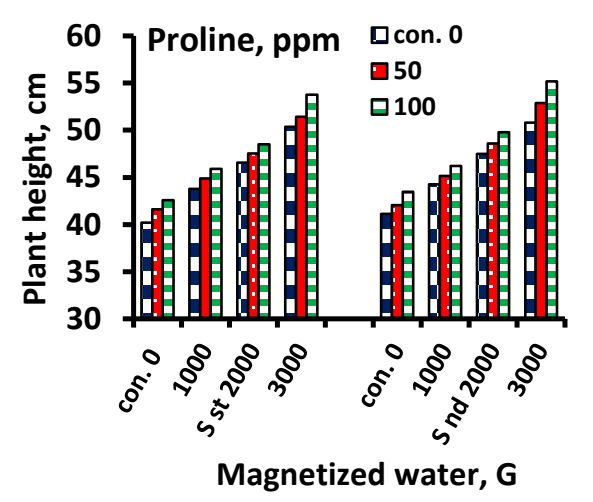

Fig.11: The effect of magnetized water on the plant height at using proline extracts.

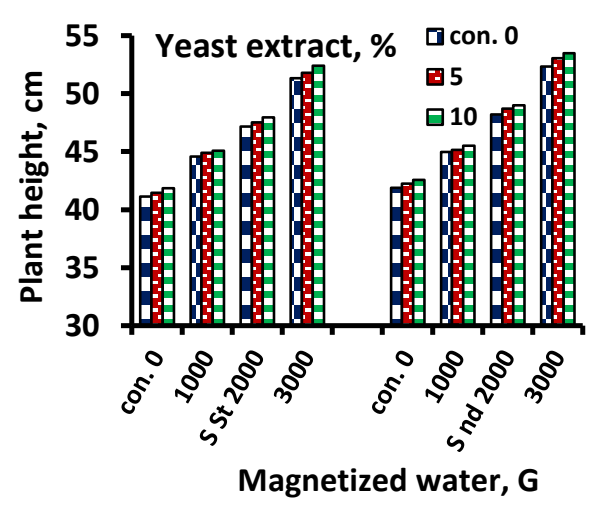

Fig.12: The effect of magnetized water on the plant height at using yeast extracts.

\section{5- Plant leaves area (A)}

In addition, the effects of the three applied treatments $\left(\mathrm{G}_{\mathrm{w}}, \mathrm{P}\right.$ and $\left.\mathrm{Y}\right)$ on the plant leaves area $\left(\mathrm{A}, \mathrm{cm}^{2}\right)$ at two different seasons are illustrated in Figs. (13 \& 14). Also, increasing the electromagnetic field density for the magnetized water $\left(G_{w}\right)$ increases the $\left(A, \mathrm{~cm}^{2}\right)$ with increasing the treatments of the $(P \& Y)$ in direct relationships. The minimum mean values of $(\mathrm{A})$ were $(748.81 \&$ $782.35 \mathrm{~cm}^{2}$ ) without using magnetized water for control plots, while the maximum mean values of the (A) were $\left(1052.10 \& 1060.49 \mathrm{~cm}^{2}\right)$ for $3000 \mathrm{G}$ of $\left(\mathrm{G}_{\mathrm{w}}\right)$ at $(\mathrm{P})$ of $100 \mathrm{ppm}$, as shown in Fig. (13). The increment ratios in A were $(28.83 \& 26.23 \%)$ than control for (2015 \& 2016) seasons respectively. Likewise, the minimum mean values of (A) were $\left(767.09 \& 801.89 \mathrm{~cm}^{2}\right)$, as 
shown in Fig. (14) without using magnetized water for control plots, while the minimum mean values of the (A) were $\left(1031.90 \& 1046.78 \mathrm{~cm}^{2}\right)$ for $3000 \mathrm{G}$ of $\left(\mathrm{G}_{\mathrm{w}}\right)$ at $(\mathrm{Y})$ of $10 \%$. The increment ratios in A were (25.66 \& 23.39 $\%)$ than control for $(2015 \& 2016)$ seasons respectively. These results in consequence of using proline and yeast extracts stimulated the plant essential enzymes which increases relatively the plant leaves area under using the magnetized water. Statically, there are high significant effects for the total interaction between different treatments with $(\mathrm{P}<0.05)$ for the $(\mathrm{A})$ values. As well, ANOVA analysis indicated highly significant differences between the treatments. A simple power regression analysis applied to relate the change in (A) with the change in the tested factors for all treatments. The obtained regression equations for the two different seasons were in the form of:

(A S ${ }^{\text {St }}$ ) $\mathrm{cm}^{2}=769.165+0.0754 \mathrm{~W}(\mathrm{G})+0.545 \mathrm{P}(\mathrm{ppm})+1.987 \mathrm{Y}(\%)$ $\left(\mathbf{R}^{2}=0.9988 \& \mathbf{C} . \mathbf{V}=0.420\right)$
(A S $\left.{ }^{\text {nd }}\right) \mathrm{cm}^{2}=804.229+0.071 \mathrm{~W}$
$(\mathrm{G})+0.452 \mathrm{P}(\mathrm{ppm})+1.855 \mathrm{Y}(\%)$ $\left(\mathbf{R}^{2}=0.9989 \& \mathbf{C} . \mathbf{V}=0.368\right)$

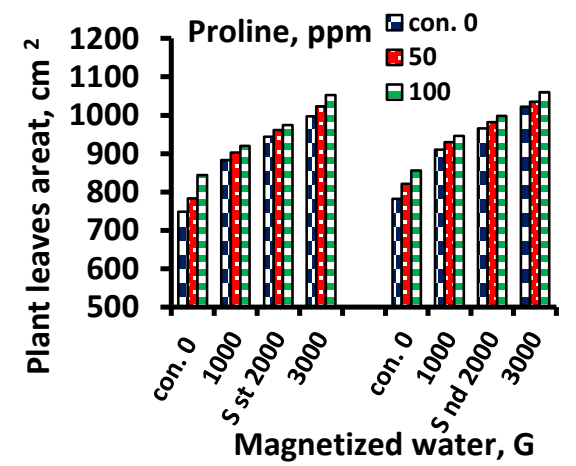

Fig.13: The effect of magnetized water on the plant leaves area at using proline extracts.

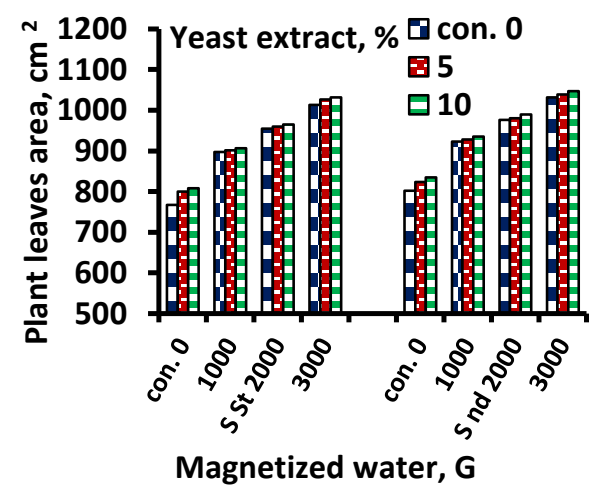

Fig.14: The effect of magnetized water on the plant leaves area at using yeast extracts.

\section{6- Plant leaves chlorophyll percentage $(\mathrm{Ch})$}

Obviously, the effects of the three applied treatments $\left(\mathrm{G}_{\mathrm{w}}, \mathrm{P}\right.$ and $\left.\mathrm{Y}\right)$ on the plant leaves chlorophyll percentage $\left(\mathrm{Ch}, \mathrm{mg} / \mathrm{cm}^{2}\right)$ at the tested seasons are shown in Figs. (15\&16). Too, increasing the electromagnetic field density for the magnetized water $\left(\mathrm{G}_{\mathrm{w}}\right)$ increases the $(\mathrm{Ch})$ with increasing the treatments of the $(\mathrm{P} \& \mathrm{Y})$ in direct relationships. The minimum mean values of $(\mathrm{Ch})$ were 
$\left(0.415 \& 0.430 \mathrm{mg} / \mathrm{cm}^{2}\right)$ without using magnetized water for control plots, while the maximum mean values of the $(\mathrm{Ch})$ were $\left(0.574 \& 0.578 \mathrm{mg} / \mathrm{cm}^{2}\right)$ for $3000 \mathrm{G}$ of $\left(\mathrm{G}_{\mathrm{w}}\right)$ at $(\mathrm{P})$ of $100 \mathrm{ppm}$, as shown in Fig. (15). The increment ratios in Ch were $(27.70 \& 25.61 \%)$ than control for $(2015 \& 2016)$ seasons respectively. As shown in Fig. (16), the minimum mean values of (Ch) were $\left(0.425 \& 0.441 \mathrm{mg} / \mathrm{cm}^{2}\right)$ without using magnetized water for control plots, while the maximum mean values of the $(\mathrm{Ch})$ were $\left(0.563 \& 0.571 \mathrm{mg} / \mathrm{cm}^{2}\right)$ for $3000 \mathrm{G}$ of $\left(\mathrm{G}_{\mathrm{w}}\right)$ at $(\mathrm{Y})$ of $10 \%$. The increment ratios in Ch were $(24.51 \&$ $22.77 \%$ ) than control for (2015 \& 2016) seasons, respectively. The observed results may be attributed to by increasing the electromagnetic field densities with using the proline and yeast extracts the number of leaves increased with the true healthy vegetative growth which produces more chlorophyll percentages. Too, ANOVA analysis indicated highly significant differences between the treatments. There are high significant effects statically for the total interaction between different treatments with $(\mathrm{P}<0.05)$ for the $(\mathrm{Ch})$ values. A simple power regression analysis applied to relate the change in $(\mathrm{Ch})$ with the change in the tested factors for all treatments. The obtained regression equations for the two different seasons were in the form of:

$\left(\right.$ Ch S $\left.{ }^{\text {St }}\right) \mathrm{mg} / \mathrm{cm}^{2}=0.423+4.052 \mathrm{e}^{-5} \mathrm{~W}(\mathrm{G})+2.825 \mathrm{e}^{-4} \mathrm{P}(\mathrm{ppm})+9.33 \mathrm{e}^{-4} \mathrm{Y}(\%)$ $\left(\mathbf{R}^{2}=0.9987 \& \mathbf{C} . \mathbf{V}=0.417\right)$

(Ch S $\left.{ }^{\text {nd }}\right) \mathrm{mg} / \mathrm{cm}^{2}=0.44+3.838 \mathrm{e}^{-5} \mathrm{~W}(\mathrm{G})+2.369 \mathrm{e}^{-4} \mathrm{P}(\mathrm{ppm})+9.194 \mathrm{e}^{-4} \mathrm{Y}(\%)$ $\left(\mathbf{R}^{2}=0.9988\right.$ \& $\left.\mathbf{C} . \mathbf{V}=0.366\right)$

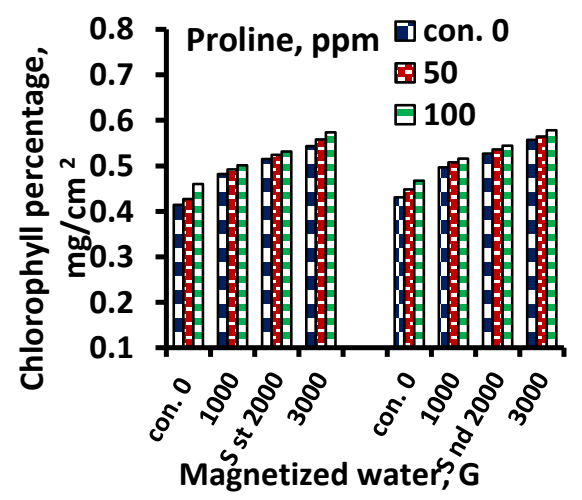

Fig.15: The effect of magnetized water on the chlorophyll percentage at using proline extracts.

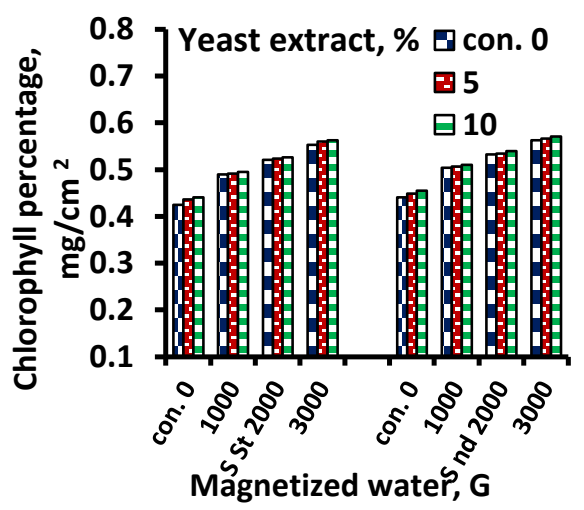

Fig.16: The effect of magnetized water on the chlorophyll percentage at using yeast extracts. 


\section{7- Plant flowering time (F)}

Figs. (17\& 18) are illustrated the effects of the three applied treatments $\left(\mathrm{G}_{\mathrm{w}}, \mathrm{P}\right.$ and $\left.\mathrm{Y}\right)$ on the plant flowering time (F, day) at tested seasons. As well, increasing the electromagnetic field density for the magnetized water $\left(\mathrm{G}_{\mathrm{w}}\right)$ raises the $(\mathrm{F})$ with increasing the treatments of the $(\mathrm{P} \& \mathrm{Y})$ in direct relationships. The minimum mean values of $(\mathrm{F})$ were $(62 \& 65$ day) without using magnetized water for control plots, when the highest mean values of the $(\mathrm{F})$ were $\left(86 \& 87\right.$ day) for $3000 \mathrm{G}$ of $\left(\mathrm{G}_{\mathrm{w}}\right)$ at $(\mathrm{P})$ of 100 ppm, as shown in Fig. (17). The increment ratios in (F) were (27.91 \& $25.29 \%$ ) than control for (2015 \& 2016) seasons respectively. Moreover, the minimum mean values of $(\mathrm{F})$ were $(64 \& 67$ day), as shown in Fig. (18) without using magnetized water for control plots, while the maximum mean values of the $(\mathrm{F})$ were $\left(84 \& 86\right.$ day) for $3000 \mathrm{G}$ of $\left(\mathrm{G}_{\mathrm{w}}\right)$ at $(\mathrm{Y})$ of $10 \%$. The increment ratios in $(\mathrm{F})$ were $(23.81 \& 22.09 \%)$ than control for (2015 \& 2016) seasons respectively. These results may be ascribable for the increasing change in the structure of the tissues of the plant cellular and the synthesis of proteins, which contributed to prolong the flowering period to a large degree, increasing the proportion of the contract and thus increase the amount of yield using yeast and proline under the levels of magnetized water.

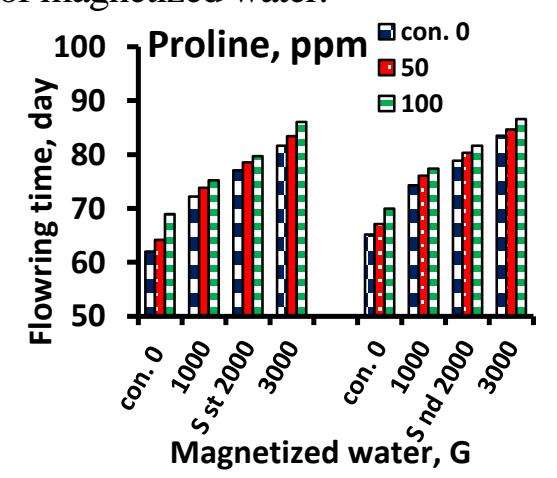

Fig.17: The effect of magnetized water on the plant flowering time at using proline extracts.

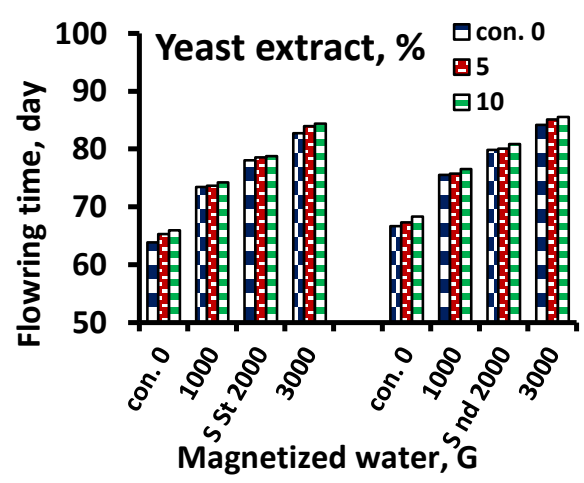

Fig.18: The effect of magnetized water on the plant flowering time at using yeast extracts.

Too, there are high significant effects statically for the total interaction between different treatments with $(\mathrm{P}<0.05)$ for the $(\mathrm{F})$ values. Also, ANOVA analysis indicated highly significant differences between the treatments. A 
simple power regression analysis applied to relate the change in $(F)$ with the change in the tested factors for all treatments. The obtained regression equations for the two different seasons were in the form of:

$\left(\right.$ F S $\left.^{\text {St }}\right)$ day $=63.371+0.0061 \mathrm{~W}(\mathrm{G})+0.0428 \mathrm{P}(\mathrm{ppm})+0.131 \mathrm{Y}(\%)$ $\left(\mathbf{R}^{2}=0.9978\right.$ \& $\left.\mathbf{C . V}=0.542\right)$

$$
\begin{aligned}
& \left(\mathbf{F ~ S}^{\mathbf{n d}}\right) \text { day }=66.286+0.0057 \mathrm{~W}(\mathrm{G})+0.0344 \mathrm{P}(\mathrm{ppm})+0.125 \mathrm{Y}(\%) \\
& \left(\mathbf{R}^{2}=0.9980 \text { \& } \mathbf{C . V}=0.467\right)
\end{aligned}
$$

\section{8- Crop yield (y)}

Clearness, the effects of the three applied treatments $\left(\mathrm{G}_{\mathrm{w}}, \mathrm{P}\right.$ and $\left.\mathrm{Y}\right)$ on crop yield (y, ton/fed) at tested seasons are illustrated in Figs. (19\& 20). Also, increasing the electromagnetic field density for the magnetized water $\left(\mathrm{G}_{\mathrm{w}}\right)$ increases the $(\mathrm{y})$ with increasing the treatments of the $(\mathrm{P} \& \mathrm{Y})$ in direct relationships. The lowest mean values of $(\mathrm{y})$ were $(10.03 \& 10.43$ ton/fed) without using magnetized water for control plots, as the maximum mean values of the $(\mathrm{y})$ were $\left(14.35 \& 14.46\right.$ ton/fed) for $3000 \mathrm{G}$ of $\left(\mathrm{G}_{\mathrm{w}}\right)$ at $(\mathrm{P})$ of 100 ppm, as shown in Fig. (19). The increment ratios in y were (30.10 \& 27.87\%) than control for (2015 \& 2016) seasons respectively. As well, the minimum mean values of $(\mathrm{y})$ were $(10.28 \& 10.69$ ton/fed), as shown in Fig. (20) without using magnetized water for control plots, while the maximum mean values of the $(\mathrm{y})$ were $\left(14.07 \& 14.27\right.$ ton/fed) for $3000 \mathrm{G}$ of $\left(\mathrm{G}_{\mathrm{w}}\right)$ at $(\mathrm{Y})$ of $10 \%$. The increment ratios in y were (26.94 \& $25.09 \%)$ than control for (2015 $\& 2016)$ seasons, respectively. These results may on account of prolonging the period of flowering leads to increase the amount of fruits on one plant and increase the number of groups up to four times, which leads to increase the amount of the crop using yeast and proline under the levels of magnetized water. Statically, there are high significant effects for the total interaction between different treatments with $(\mathrm{P}<0.05)$ for the $(\mathrm{y})$ values. Too, ANOVA analysis indicated highly significant differences between the treatments. A simple power regression analysis applied to relate the change in (y) with the change in the tested factors for all treatments. The obtained regression equations for the two different seasons were in the form of:

$\left(\mathbf{y ~ S}{ }^{\text {St}}\right)$ ton/fed $=10.402+0.00105 \mathrm{~W}(\mathrm{G})+0.0079 \mathrm{P}(\mathrm{ppm})+0.032 \mathrm{Y}(\%)$ $\left(\mathbf{R}^{2}=0.9988 \& \mathbf{C . V}=0.423\right)$

$\left(\mathbf{y ~ S}{ }^{\text {nd }}\right)$ ton/fed $=10.850+9.9274 \mathrm{e}^{-4} \mathrm{~W}(\mathrm{G})+0.0068 \mathrm{P}(\mathrm{ppm})+0.031 \mathrm{Y}(\%)$ $\left(\mathbf{R}^{2}=0.9990\right.$ \& $\left.\mathbf{C} . \mathbf{V}=0.368\right)$ 


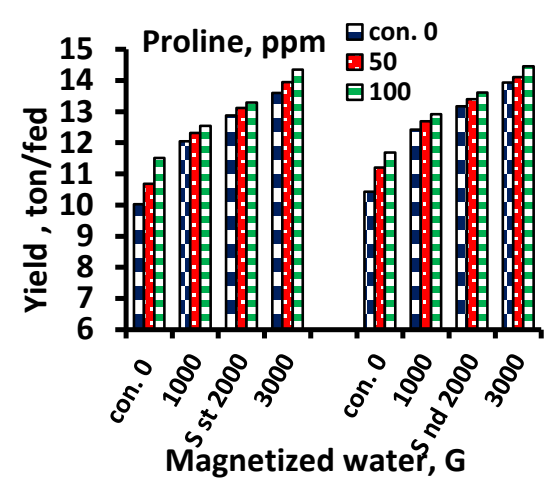

Fig.19: The effect of magnetized water on the crop yield at using proline extracts.

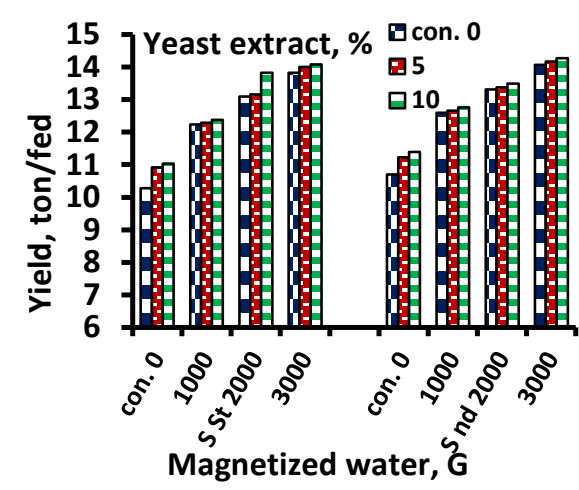

Fig.20: The effect of magnetized water on the crop yield at using yeast extracts.

\section{9- Tomato quality characteristics (chemical analysis)}

As listed in table (2) the average values of tomato crop chemical analysis at using the magnetized water levels, proline and yeast extract levels showed increment of the plant minerals, carbohydrates and crude fibers than the control plots at the tested two seasons to get the best results at the $\left(\mathrm{G}_{\mathrm{w}}\right)$ of $3000 \mathrm{G}$ with $(\mathrm{P})$ of $100 \mathrm{ppm}$ and $(\mathrm{Y})$ of $10 \%$. The significant variations in tomato fruit quality traits were obvious due to quality of irrigation water. Using proline and yeast extracts gave significantly higher magnitudes of fruit weight and vitamin $\mathrm{C}$ content than the untreated control plots, in seasons (2015 \& 2016), as listed in table (3). As average of the two seasons, irrigation with magnetized water gave heavier fruit weight and more content of vitamin $\mathrm{C}$ than control plots by $34.2 \%$ and $33.50 \%$, orderly. Also the average of the two seasons, irrigation with magnetized water at high electromagnetic density gave significantly higher values of total soluble solids (T.S.S.) and acidity $(\mathrm{pH})$ than untreated control plots by $(9.39 \& 9.0 \%)$ and $(0.390 \& 0.405 \%)$, orderly. However, the blossom end rots were decreased under the tested variables to minimum levels $(7.90 \& 8 \%)$ only due to the increasing of plant immunity due to the active oxygen by magnetized water, which eliminates a high percentage of pathogens. The positive effect of irrigation with saline water on (T.S.S.) content of fruits probably aroused as a result of reduction in water intake by the fruits (Al-Yahyai, 2010). Moreover, using proline and yeast extract make an active 
accumulation of solutes, which were mainly ions and organic molecules, occurred. The enhancing effect of irrigation with saline water on acidity is in harmony with those of who reported a positive relationship between salinity rate in irrigation water and acidity in tomato fruits.

Table.2: The average values of tomato crop chemical analysis at using the magnetized water, proline and yeast extract levels.

\begin{tabular}{|c|c|c|c|c|c|c|c|c|c|c|c|}
\hline \multirow{2}{*}{\multicolumn{2}{|c|}{$\begin{array}{l}\text { Chemical } \\
\text { analysis \% }\end{array}$}} & \multicolumn{4}{|c|}{ Magnetized water $\left(\mathbf{G}_{w}\right) \mathbf{G}$} & \multicolumn{3}{|c|}{ Proline (P) ppm } & \multicolumn{3}{|c|}{ Yeast (Y) \% } \\
\hline & & Con. & 1000 & 2000 & 3000 & Con. & 50 & 100 & Con. & 5 & 10 \\
\hline \multirow{2}{*}{$\mathbf{N}$} & $\mathbf{S}^{\text {st }}$ & 3.00 & 3.20 & 3.50 & 3.70 & 2.90 & 3.10 & 3.30 & 2.30 & 2.90 & 3.0 \\
\hline & $S^{\text {nd }}$ & 2.70 & 3.10 & 3.30 & 3.30 & 2.80 & 3.00 & 3.10 & 2.00 & 2.70 & 2.90 \\
\hline \multirow{2}{*}{$\mathbf{P}$} & $\mathbf{S}^{\text {st }}$ & 0.250 & 0.317 & 0.347 & 0.390 & 0.240 & 0.350 & 0.370 & 0.230 & 0.320 & 0.350 \\
\hline & $S^{\text {nd }}$ & 0.240 & 0.307 & 0.337 & 0.380 & 0.230 & 0.330 & 0.360 & 0.220 & 0.290 & $\mathbf{0 . 3 0}$ \\
\hline \multirow{2}{*}{$\mathbf{K}$} & $\mathrm{S}^{\text {st }}$ & 1.796 & 1.991 & 2.050 & 2.120 & 1.70 & 2.050 & 2.10 & 1.60 & 1.90 & 2.0 \\
\hline & $S^{\text {nd }}$ & 1.60 & 1.72 & 1.80 & 2.040 & 1.60 & 1.95 & 2.05 & 1.55 & 1.80 & 1.95 \\
\hline \multirow{2}{*}{ Ca } & $\mathrm{S} \mathrm{st}^{\text {st }}$ & 1.538 & 1.656 & 1.688 & 1.728 & 1.50 & 1.670 & 1.750 & 1.30 & 1.50 & 1.670 \\
\hline & $S^{\text {nd }}$ & 1.50 & 1.60 & 1.650 & 1.70 & 1.40 & 1.60 & 1.70 & 1.20 & 1.40 & 1.50 \\
\hline \multirow{2}{*}{$\mathbf{N a}$} & $\mathbf{S}^{\text {st }}$ & 0.226 & 0.062 & 0.042 & 0.027 & 0.220 & 0.040 & 0.035 & 0.225 & 0.050 & 0.040 \\
\hline & $S^{\text {nd }}$ & 0.250 & 0.070 & 0.052 & 0.037 & 0.230 & 0.050 & 0.037 & 0.230 & 0.055 & 0.045 \\
\hline \multirow{2}{*}{$\begin{array}{l}\text { Crude } \\
\text { protein }\end{array}$} & S $^{\text {st }}$ & 15.00 & 19.00 & 20.09 & 20.26 & 14.0 & 19.70 & 20.0 & 13.12 & 17.26 & 18.0 \\
\hline & $S^{\text {nd }}$ & 14.5 & 18.61 & 19.36 & 19.92 & 14.10 & 18.90 & 19.0 & 12.12 & 16.25 & 17.22 \\
\hline \multirow{2}{*}{$\begin{array}{c}\text { DW } \\
\text { mg/gm }\end{array}$} & $S^{\text {st }}$ & 200.50 & 213.60 & 218.20 & 223.40 & 200.50 & 216.30 & 220.20 & 180.65 & 203.17 & 210.20 \\
\hline & $S^{\text {nd }}$ & 200.0 & 210.50 & 212.80 & 217.30 & 200.0 & 214.90 & 218.60 & 170.16 & 190.87 & 200.93 \\
\hline
\end{tabular}

Table.3: The average values of tomato quality factors at using the magnetized water, proline and yeast extracts levels.

\begin{tabular}{|c|c|c|c|c|c|c|c|c|}
\hline \multirow{2}{*}{$\begin{array}{c}\text { Magnetized } \\
\text { water }\left(\mathbf{G}_{w}\right) \mathbf{G}\end{array}$} & \multicolumn{2}{|c|}{$\begin{array}{c}\text { Ascorbic acid } \\
\mathrm{Mg} / 100 \mathrm{~g}\end{array}$} & \multicolumn{2}{|c|}{ T.S.S \% } & \multicolumn{2}{|c|}{ Acidity \% } & \multicolumn{2}{|c|}{ Blossom end rote $\%$} \\
\hline & $\mathbf{S}^{\mathbf{S t}}$ & $\mathbf{S}^{\text {nd }}$ & $\mathbf{S}^{\text {St }}$ & $S^{\text {nd }}$ & $\mathbf{S}^{\mathrm{St}}$ & $S^{\text {nd }}$ & $\mathbf{S}^{\text {St }}$ & $S^{\text {nd }}$ \\
\hline control & 25.30 & 23.00 & 5.40 & 5.10 & 0.480 & 0.487 & 20.12 & 27.13 \\
\hline 1000 & 30.00 & 28.20 & 7.42 & 7.00 & 0.410 & 0.415 & 14.14 & 16.60 \\
\hline 2000 & 31.37 & 30.17 & 7.36 & 7.30 & 0.400 & 0.407 & 13.20 & 14.93 \\
\hline 3000 & 34.20 & 33.50 & 9.39 & 9.00 & 0.390 & 0.405 & 7.90 & 8.00 \\
\hline \multirow{2}{*}{$\begin{array}{l}\text { Proline extract } \\
\text { (P) ppm }\end{array}$} & \multicolumn{2}{|c|}{$\begin{array}{l}\text { Ascorbic acid } \\
\mathrm{Mg} / 100 \mathrm{~g}\end{array}$} & \multicolumn{2}{|c|}{ T.S.S \% } & \multicolumn{2}{|c|}{ Acidity \% } & \multicolumn{2}{|c|}{ Blossom end rote $\%$} \\
\hline & $\mathbf{S}^{\text {St }}$ & $\mathbf{S}^{\text {nd }}$ & $\mathbf{S}^{\mathrm{St}}$ & $S^{\text {nd }}$ & $\mathbf{S}^{\text {St }}$ & $S^{\text {nd }}$ & $\mathbf{S}^{\mathbf{S t}}$ & $S^{\text {nd }}$ \\
\hline control & 24.20 & 24.00 & 5.30 & 5.20 & 0.489 & 0.485 & 25.0 & 25.40 \\
\hline 50 & 31.00 & 30.90 & 7.30 & 7.90 & 0.407 & 0.405 & 16.60 & 18.00 \\
\hline 100 & 33.00 & 32.70 & 9.30 & 9.00 & 0.403 & 0.400 & 13.00 & 13.98 \\
\hline \multirow{2}{*}{$\begin{array}{l}\text { Proline extract } \\
\text { (Y) } \%\end{array}$} & \multicolumn{2}{|c|}{$\begin{array}{c}\text { Ascorbic acid } \\
\mathrm{Mg} / \mathbf{1 0 0} \mathrm{g}\end{array}$} & \multicolumn{2}{|c|}{ T.S.S \% } & \multicolumn{2}{|c|}{ Acidity \% } & \multicolumn{2}{|c|}{ Blossom end rote $\%$} \\
\hline & $\mathbf{S}^{\mathbf{S t}}$ & $S^{\text {nd }}$ & $\mathbf{S}^{\mathbf{S t}}$ & $S^{\text {nd }}$ & $\mathbf{S}^{\mathbf{S t}}$ & $S^{\text {nd }}$ & $\mathbf{S}^{\mathbf{S t}}$ & $S^{\text {nd }}$ \\
\hline control & 22.28 & 21.28 & 5.00 & 5.00 & 0.490 & 0.500 & 25.01 & 26.04 \\
\hline 5 & 30.47 & 29.34 & 6.90 & 6.50 & 0.430 & 0.460 & 18.60 & 18.70 \\
\hline 10 & 32.13 & 31.98 & 8.50 & 7.50 & 0.420 & 0.440 & 11.80 & 12.33 \\
\hline $\begin{array}{l}\text { The best tomato } \\
\text { quality using } \\
\left(G_{w}\right) 3000 G\end{array}$ & 34.20 & 33.50 & 9.39 & 9.00 & 0.390 & 0.405 & 7.90 & 8.00 \\
\hline
\end{tabular}


10- Cost estimation: An economical study was done to limit the net profit according to use the tested variables in comparison of the control area at the different two seasons, as listed table (4). The collected analyzed data showed the significant effects of using the tested variables which raised the total earn by $(33.19 \& 30.24 \%)$ orderly through seasons (2015\&2016) over the control due to changing prices which proved that used technique was more successful economically.

Table.4: The cost estimation for tomato crop through the tested seasons.

\begin{tabular}{|c|c|c|c|c|}
\hline Parameters & $\begin{array}{c}\text { Control } \\
2015 \\
\end{array}$ & $\begin{array}{c}\text { Control } \\
2015 \\
\end{array}$ & $\begin{array}{c}\text { Season } \\
2015\end{array}$ & $\begin{array}{c}\text { Season } \\
2016\end{array}$ \\
\hline Yield production (ton/fed) & 10.03 & 10.43 & 14.35 & 14.46 \\
\hline Yield cost $($ L.E/fed) & 30090 & 52150 & 43050 & 72300 \\
\hline Weed control cost $($ L.E/fed) & 750 & 790 & 300 & 320 \\
\hline Soil preparation cost $(\mathrm{L} . \mathrm{E} / \mathrm{fed})$ & 350 & 350 & 350 & 350 \\
\hline Planting cost (L.E/fed) & 500 & 500 & 500 & 500 \\
\hline Irrigating cost (L.E/fed) & 300 & 300 & 300 & 300 \\
\hline Labor cost $($ L.E/fed) & 250 & 250 & 250 & 250 \\
\hline Fertilizing cost (L.E/fed) & 850 & 950 & 300 & 320 \\
\hline Net earn (L.E/fed) & 27090 & 49010 & 40550 & 70260 \\
\hline \multicolumn{3}{|c|}{$\begin{array}{l}\text { Increment ratios \% } \\
\end{array}$} & $33.19 \%$ & $30.24 \%$ \\
\hline \multicolumn{5}{|c|}{ Notice (price was 3 L.E /kg season 2015 while it was 5 L.E/kg season 2016) } \\
\hline
\end{tabular}

\section{CONCLUSION}

\section{The main results could be summarized as the following:}

1- The reduction ratios in $\mathrm{EC}$ and $\mathrm{pH}$ were $(45.09 \& 50.19 \%)$ and $(28.93$ $\& 31.86 \%)$ than control for (2015 \& 2016) seasons respectively at using electromagnetic density of the magnetized water $\left(G_{w}\right)$ of $3000 \mathrm{G}$ for proline $(\mathrm{P}) 100 \mathrm{ppm}$ using yeast extract $(\mathrm{Y})$ of $10 \%$.

2- The increment ratios in germination ratio $(\mathrm{G})$ and plant heights $(\mathrm{H})$ were $(26.62 \& 25.08 \%)$ and $(25.19 \& 25.41 \%)$ while, the increment ratios in plant leaves area (A) and chlorophyll percentages $(\mathrm{Ch})$ were $(28.83 \& 26.23 \%)$ and $(27.70 \& 25.61 \%)$ than control for $(2015 \&$ 2016) seasons orderly at the same factors levels.

3- The increment ratios in plant flowering time $(\mathrm{F})$ were $(27.91$ \& $25.29 \%)$ than control for (2015 \& 2016) at the same factors levels.

4- The increment ratios in tomato quality qualities (T.S.S.) and (vit. C) were $(9.39 \& 9.0 \%)$ and $(34.2 \% \& 33.50 \%)$ while, the reduction ratios 
of (tomato acidity and blossom end rots ratios) were $(0.390 \& 0.405$ $\%)$ and (7.90 \& 8\%) only for (2015 \& 2016) seasons respectively.

5- The increment ratios in crop yield (y) and the net earn were (30.10 \& $27.87 \%)$ and (33.19 \& 30.24\%) orderly than control for (2015 \& 2016) seasons at the same factors levels.

So we recommend using this technique to enlargement the production and crops quality in Egypt.

\section{REFERENCES}

Abbas, S. M. (2013). The influence of biostimulants on the growth and on the biochemical composition of Vicia fava CV. Giza 3 beans. Romanian Biotechnological Letters, 18 (2):8061-8068.

Alsadon, A. A., Wahb-Allah, M. A. and S.O. Khalil. (2009). Evaluation of salinity tolerance of tomato cultivars, breeding lines and their hybrid combinations under greenhouse conditions. Acta Hort. 807:207 - 214.

Al-Yahyai, R., S. Al-Ismaily, and A.S. Al-Rawahy (2010). Growing tomatoes under saline field conditions and the role of fertilizers. A Monograph on management of salt-affected soils and water for sustainable agriculture, Sultan Qaboos University. 42(2):P.P., 8388.

Amiri, M.C.; and A.A. Dadkhah (2006). On reduction in the surface tension of water due to magnetic treatment. Colloids Surf A: Physicochem Eng Aspects, 278: 252-255.

Beckles, D. M. (2011). Factors affecting the postharvest soluble solids and sugar content of tomato (Solanum lycopersicumL.) Fruit. Postharvest Biology and Technology, 63 (1): 129-140.

Behrouz, E. M.; C. Abdolkarim; Y.Nafiseh; and L. Bahareh (2010). Plants in copper and iron mine in Iran, Pakistan journal of biological science, 11(3), pp 490-4. Identification of the hyper accumulator 92.

Chibowski, E.; A. Szcześ; and L. Hołysz (2005). Influence of Sodium Dodecyl Sulfate and Static Magnetic Field on the Properties of Freshly Precipitated Calcium Carbonate. ACS Publications. 21(18): 8114-8122. 
Costa, J.; M., Ortuno, M. F. and M. M. Chaves. (2007). Deficit irrigation as a strategy to save water: physiology and potential application to horticulture. J. Integr. Plant Biol. 49: 1421-1434.

Dinkha, R.F. and T.O. Al-Khazragji (1990). Nutrition and fungus function science, University of Salahaddin, Ministry ofHigh Educati on, Iraq. (In Arabic).

El-Sayed, A.S.; W.F. El-Metwally and M.E. El_Iraqi (2015). "Developing bio-treatment unit for irrigating the salt-affected soils by magnetization and UV" 4th international conference of Agricultural\& Bio- Engineering. Egypt. J. Agric. Res., 93 (5) PP.15-40.

Giovannucci, E. (1999). Tomatoes tomato-based products, lycopene and canser: Review of the epidemiologic literature. J. Nat. Cancer Inst. 91: 317-331.

Hamilton, E. W. and S.A. Heckathorn (2001). Mitochondrial adaptations to $\mathrm{NaCl}$. Complex $\mathrm{I}$ is protected by antioxidants and small heat shock proteins, whereas complex II is protected by proline and betaine. Plant Physiology 2001; 126: 1266-1274.

Hashem, M.; Y. M. Omran, and S. M. Nashwa (2008). Efficacy of yeasts in the management ofroot-knot nematode (Meloidogyne incognita) in flame seedless grape vines and the consequent on the productivity of the vines. Biocontrol Science and Technology 18(4): 357-375.

Hayashi, F.; T. Ichino; M. Osanai and K. Wada (2000). Oscillation and regulation of proline content by $\mathrm{P} 5 \mathrm{CS}$ and $\mathrm{ProDH}$ gene expressions in the light/dark cycles in Arabidopsis thaliana L. Plant and Cell Physiology 2000; 41: 1096-1101.

Hilal, M.H. and M.M. Hillal (2000). Application of magnetic technologies in desert agriculture .1-Seed germination and seedling emergence of some crop in a saline calcareous soil. Egypt J. Soil Sci. 40 :(3): 413-421.

Hoque, M.A.; M.N. Banu; E. Okuma; K. Amako; Y. Nakamura; Y. Shimoishi and Y. Murata (2007). Exogenous proline and glycinebetaine increase $\mathrm{NaCl}$-induced ascorbate glutathione cycle enzyme activities, and proline improves salt tolerance more than glycinebetaine in tobacco Bright Yellow-2 
suspension-cultured cells. Journal of Plant Physiology 2007; 164: 1457-1468.

Lim, P. and T. Ogata (2005). Salinity effect on growth and toxin production of four tropical Alexandrium species (Dinophyceae). Toxicon. 45: 699 - 710.

Magkos, F.; F. Arvaniti and A. Zampelas (2003). Organic food: nutritious food or food for thought? A review of the evidence. Int. J. Food Sci. Nutur. 54, 357-371.

Maheshwari, B.L. and H.S. Grewal (2009). Magnetic treatment of irrigation water: Its effects on vegetable crop yield and water productivity. Agric Water Manage 96: 1229-1236.

Mahmoued, T. R. (2001). Botanical studies on the growth and germination of mahnolia (Magnolia grandiflora L.) plants. M. Sci. Thesis.Fac. Of Agric. Moshtohor, Zagazig Univ., Egypt.

Matysik, J.; B. Bhalu and P. Mohanty (2002). Molecular mechanisms of quenching of reactive oxygen species by proline under stress in plants. Curr. Sci., 82, 525-532.

Oida, A. (1997). Using personal computer for agricultural machinery management. Kyoto University. Japan. JICA publishing.

Olympios, C.M.; I.C. Karapanos; K. Lionoudakis and I. Apidianakis. (2003). The growth, yield and quality of greenhouse tomato in relation to salinity applied at different stages of plant growth. Acta Hort. 609:313-320.

Peet, M. M. (2005). Irrigation and fertilization. In: Heuvelink E, ed. Tomatoes, Crop Production Science in Horticulture. CABI Publishing, UK. pp. 171-198.

Siddiqui, M. W. (2015). Postharvest biology and technology of horticultural crops - principles and practices for quality maintenance. USA, $572 \mathrm{p}$.

Silva, J.C. and W. Bettiol (2005). Potential of nonpathogenic Fusarium oxysporum isolates for control of Fusarium wilt of tomato. Fitopatologia Brasileira 30: 409-412.

Sivakumar, P.; P. Sharmila and P. P. Saradhi (2000). Proline alleviates saltstress induced enhancement in ribulose-1, 5-bisphosphate oxygenase activity. Biochem. Biophys. Res. Commun., 279, 512-515. 
Stino, R.G.; A. T Mohsen; M. A. Maksoud; M.M.M. Abd elmigeed; A.M. Gomaa and A. Y. Ibrahim (2009). Bio-organic fertilization and its impact on Apricot young trees in newly reclaimed soil. AmerEurasian J. Agric. and Environ.Sci., 6(1): 62-69.

Tai, C.Y.; C.K. Wu; and M.C. Chang (2008). Effects of magnetic field on the crystallization of $\mathrm{CaCO} 3$ using permanent magnets. Chem. Engin. Sci., 63: 5606-5612.

Taylor, M.D. and S.J. Locascio (2004). Blossom-End Rot: A Calcium Deficiency. J. Plant Nutr. 27, 123-139.

Topcu, S.; C. Kirda ; Y.Dasgan ; H. Kaman ; M. Cetin ; A. Yazici, and M. A. Bacon (2006). Yield response and N-fertilizer recovery of tomato grown under deficit irrigation. Eur. J. Agron. 26: 64 - 70.

Voogt, W. (1998). The growth of beefsteak tomato as affected by K/Ca ratios in the nutrient solution. Glasshouse Crops Research Station Naaldwijk, The Netherlands. Plant Production in closed ecosystems 83-102.

Wanas, A. and L. Trails (2006). For improving growth and productivity of tomato plants grown in winter. Annals. Agric. Sci. Moshtohor.; 44(3):466-471.

Zhu, J. K. (2001). Cell signaling under salt, water and cold stresses. Curr. Opin. Plant Biol, 4, 401-406.

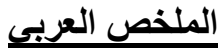

تأثير الري بالماء الممغط والرش بالبرولين ومستخلص الخميرة علي جودة المبرة

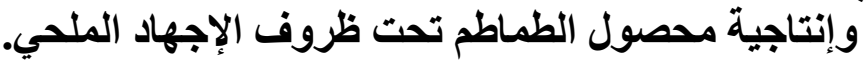

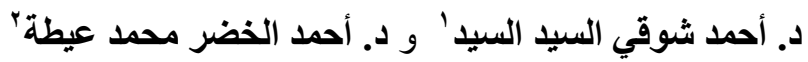

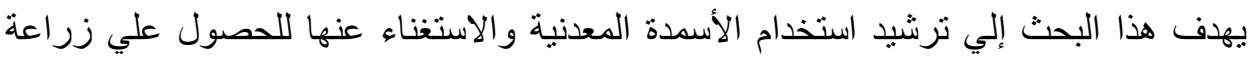

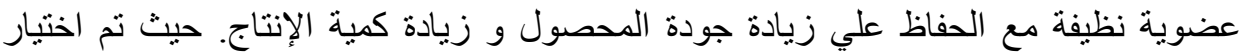

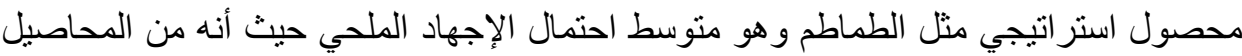

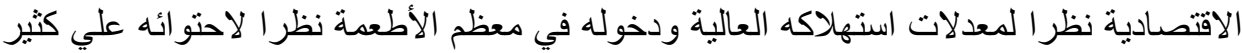
من الفيتامينات و العناصر المعدنية وحيث أنه من المحاصيل المستهلكة لمياه الري الرئية بنسبة كبيرة.

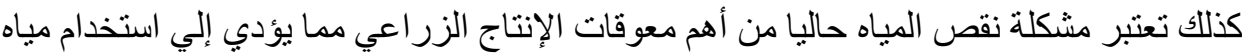

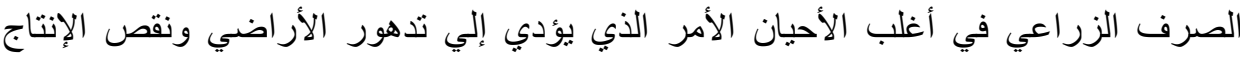

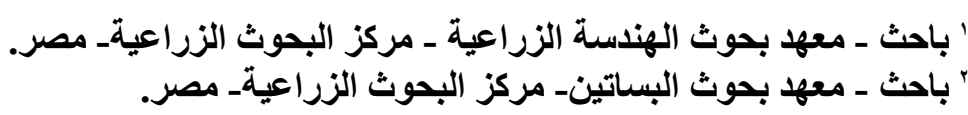


الزر اعي تدريجيا نتيجة لارتفاع نسبة الملوحة. من هنا كانت فكرة البحث بتطبيق ثناثة معاملات

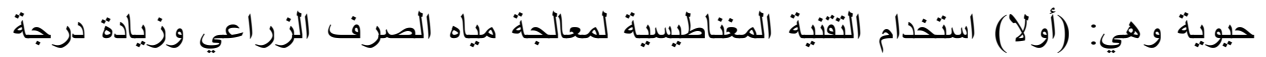
صلاحيتها للزر اعة حيث تقوم المغناطسية بتغيير الروابط الهيدروجينية وتكسير بلور ات الأملاح لبلورات أصغر حجما عديمة التأثير الاسموزي نتيجة لتأين المياه و إكسابها طاقة. حيث تم استخدام جهاز مطور تم تصنيعه وإلحاقه بماكينات الري النقالي لتوليد مجال كهرومغناطيسي منغير لتوري يحتوي علي مجموعة من الملفات المغناطيسية علي محيط ماسورة الطرد و التي تم التحكم فيها إلكترونيا بواسطة جهاز إلكتروني للتحكم في زمن المعاملة وشدة المجال المغناطيسي والتي

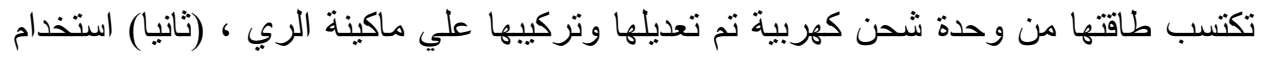

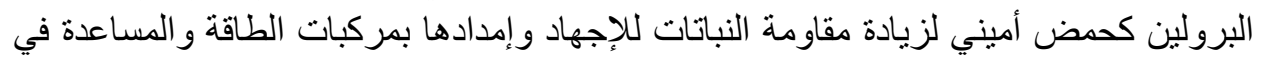
بناء أنسجتها أثناء فترة النمو، (ثالثا) استخدام مستخلص الخميرة لتحفيز إنتاج السيتوكينين

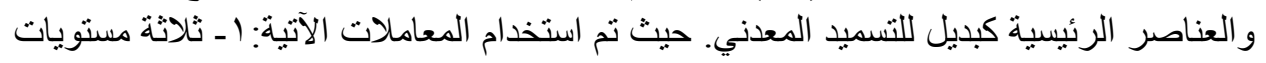

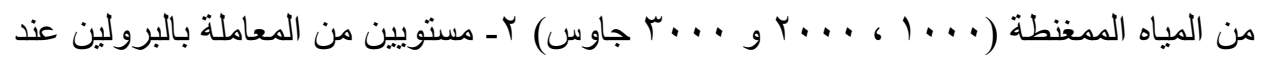

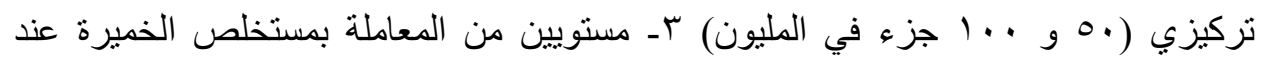

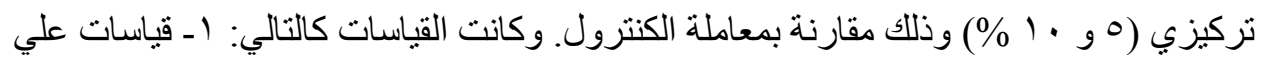

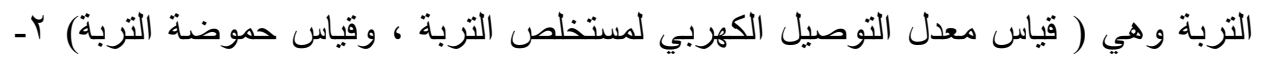

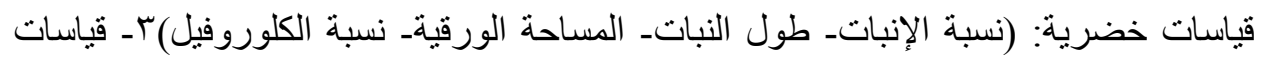

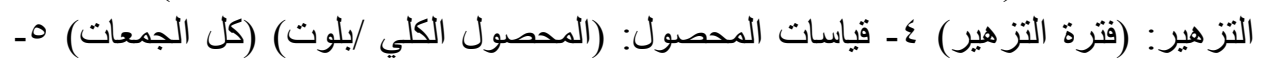

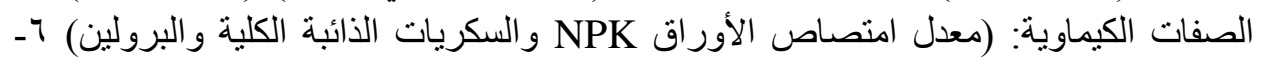

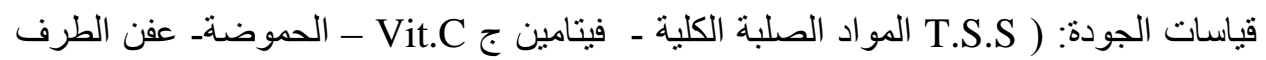

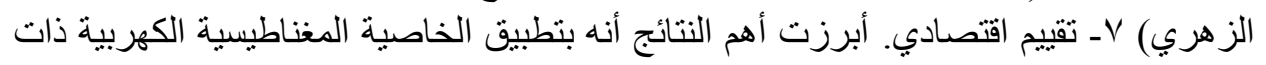

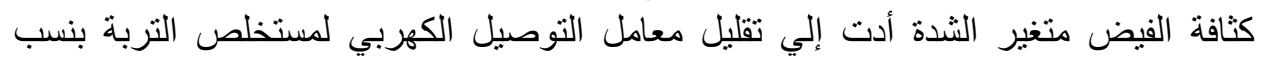
تخفيض (9 . .0؛ و 9 (. .0 \%) عن معاملة الكنترول خلال موسمي الزر اعة باستخدام كثافة

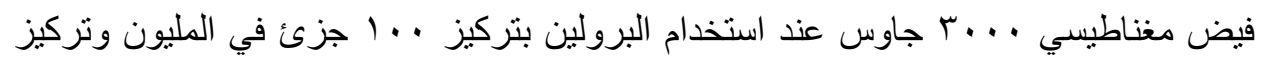

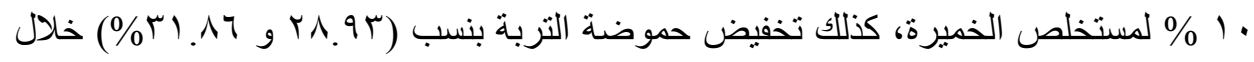
موسمي الزر اعة عند نفس المعاملات بالمقارنة بالكنترول. كذلك ارتفعت نسب متوسطات أطو ال

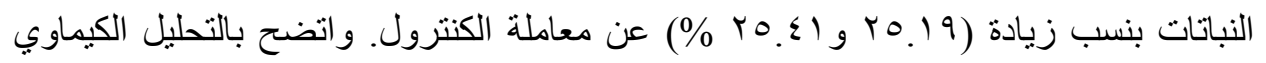

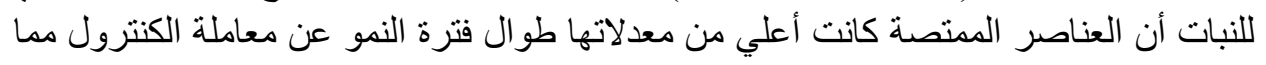

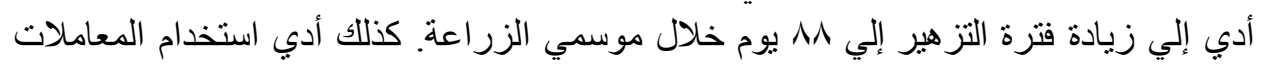

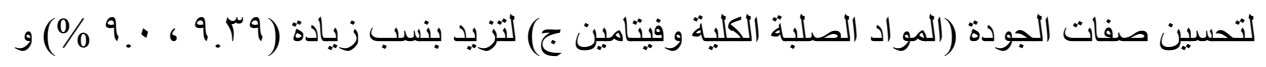

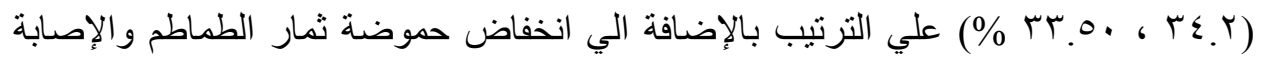

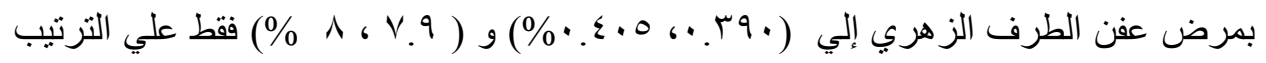
خلال موسمي الزراعة. كذلك أدي استخدام هذه المعاملات إلي زيادة إنتاجية وحدة المساحة

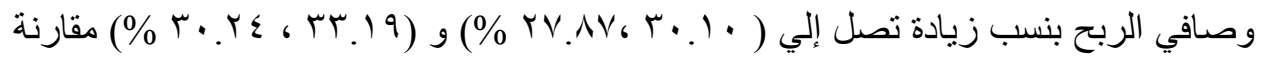

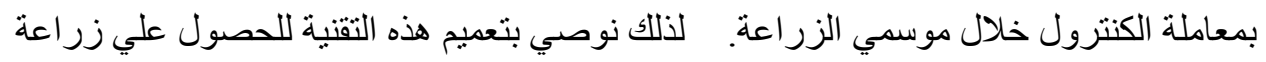
عضوية نظيفة ذات جودة وانتاجية عالية علي مستوي القطاع الزر اعي لجمهورية مصر العربية. 